\title{
AI VISION \#2 - MEDICAL LAW AND ARTIFICIAL INTELLIGENCE IN THE FUTURE OF HEALTHCARE
}

Szerző:

Dr. Zorkóczy Miklós

Zorkóczy Ügyvédi Iroda

A szerző e-mail címe:

miklos@drzorkoczy.hu
Lektorok:

Hörömpöli Tóth Levente (Dr. Jur.)

Levito \& Vever fordítóiroda

Simó Ferenc Zoltán (Dr. Jur.)

Eszterházy Károly Katolikus Egyetem

és további két anonim lektor...

\section{Absztrakt \\ AI VÍZIÓ \#2 - EGÉSZSÉGÜGYI JOG ÉS MESTERSÉGES INTELLIGENCIA AZ EGÉSZSÉGÜGY JÖVÖJÉBEN}

Az AI vision \#1 (Zorkóczy, 2021a) után, amelyben egy egészségügyi telemedicina start up életpályáját tekintettük át, most egy sokkal elméletibb felvetéssel élünk, hova vezethet a mesterséges intelligencia fejlődése és várhatóan milyen dilemmák és problémák adódhatnak ebből a fejlődésből?

Kulcsszavak: Egészségügyi jog, egészségügy, Mesterséges Intelligencia, gépi tanulás, algoritmusok, adatvédelem, Big Data, data science

Diszciplinák: egészségügyi jog, jog

\section{Abstract}

After having a ride in AI vision \# 1 (Zorkóczy, 2021a) when an AI investment was to start up a telemedicine project, this article is about asking questions of the opportunities and problems of AI development in the far future.

Keywords: medical law, Healthcare, AI, machine learning, algorithms, data privacy, Big Data, data science

Disciplines: medical law, law

Zorkóczy Miklós (2021): AI Vision \#2 - Medical Law and Artificial Intelligence in the Future of Healthcare. Mesterséges intelligencia - interdiszciplináris folyóirat, III. évf. 2021 / 2. szám. 9-18. doi: 10.35406/MI.2021.2.9 
The so-called Artificial Narrow Intelligence (ANI) systems used in the field of healthcare operate by processing real databases and applying Machine Learning (ML) methods. Such detective systems, i.e. those that are based on past and measurable calculations, or that learn along preset parameters and protocols can exist, for instance, in image diagnostics, personalized precision medicine, telemedicine analyzing measurements and facilitating communications, medical decision support systems (DSS) analyzing operations and facilitating medical management, as well as solutions accelerating virtual clinical research. The extract of my previous study (Zorkóczy, 2021b) poses questions about dilemmas and the social impact related to Artificial General Intelligence (AGI) and Artificial Superintelligence (ASI) applications that represent the next phase of AI development.

\section{MedicAI}

Artificial Intelligence ('AI') in general is a software that can imitate human capabilities. You can differentiate based on what type of AI we are talking about, what technology the application is based on, in what industry or sector it is used, or what functions it has. For the purposes of healthcare, current machine learning methods help healthcare systems with data analysis, image recognition, or language technology solutions. The definition of medical devices is determined by the MDR (Medical Devices Regulation of European
Parliament, Art. 2, point 1) according to which 'medical device' "means any instrument, apparatus, appliance, software (...) intended by the manufacturer to be used, alone or in combination, for human beings for one or more of the following specific medical purposes: diagnosis, prevention, monitoring, prediction, prognosis, treatment or alleviation of disease, diagnosis (...) of an injury or disability".

In certain professions humans are reluctant by nature to accept the fact that decisions are made by computers in their case because they don't have any trust in them and find it better to meet and talk to flesh-and-blood fellow humans who can then be held accountable when something goes sideways. Such typical areas are law and healthcare as well. As far as medical liability is concerned, you automatically associate it with malpractice damages although a number of "multi-layered" external (civil law, criminal law, misdemeanor, public administration-related) and internal (labor law and ethics) healthcare provider liabilities exist in practice. Healthcare legislation itself is very much diverse, like in the Hungarian regulation it is common to invoke protocols, best practices and ethical rules when it comes to determining the right level of healthcare provision - see: Act on Healthcare, Section 7, par. (2), Section 77, par. (3). Hence, from the point of view of provider liability, the right decision must be made not only on the basis of legislation of different level legal hierarchy but also in the maze of ethical rules of chambers of 
physicians, medical professionals and pharmacists, national and local institutional guidelines and protocols.

Physicians often complain that whilst they often must make the right decision within minutes, professional, legal and court expert procedures drag on for years to determine their liability or the lack thereof. From the AI perspective it is great news that these professional rules, directives and protocols can be transformed into decision paths by code, and they can get easy and simply accessible in up-to-date fashion thanks to an AI-driven natural language processing system. This still doesn't imply the exemption of the doctor's liability if a machine was to tell in a given situation what professional rules apply to a specific case at a certain time. Furthermore, if this system is trained with continuous feedback, even a chatbot assistant application, that is a telemedicine solution for physicians can be developed with a machine learning method. Such a system could provide additional information to the treating physician by giving predictions in terms of probability percentage. Such additional information includes how other doctors have decided in similar cases with what outcome, and what questions have been asked by others and what else they wanted to know regarding the case. However, the final decision is definitely made, and the responsibility for that decision is borne, by the doctor, so the AI system does not replace the intelligence of physicians but rather it constitutes an augmented intelligence, an intelligence of shared medical knowledge and experience.

The operator of such a medical AI system would be liable up to a certain extent, just like a developer of databases on judicial decisions and rules that monitor up-to-date, precise and current changes. In the field of chatbot assistance, on the one hand, operator liability regarding decisions must be disclaimed to start with, stressing that the databasis in question contains probabilities based on others' decisions; on the other hand, with regard to learning test - evaluating databases the operator should be liable for its relevance, retraceability and accountability. Now, that's a different story to what extent this would be accepted as reliable or be used by the medical community, what feedback could be expected, and how much data would or could be provided thereby. I believe this would be a longer work process; a basic system would first collect the national and local professional rules and directives by placing them into context with legislation. And when doctors using the system get to know its benefits, participants could then be engaged for research and later test purposes which would keep on evolving by itself.

\section{Ethics to strengthen trust}

In relation to AI in general, people have developed mistrust, which is a totally understandable human phenomenon, and which can be offset by awareness raising and trust nurturing measures from the outset. Hundreds of ethical regulations 
have been set up all around the world, and guidelines of several global and professional organizations have been published, Big Tech has come up with their own voluntary ethical schemes, and standard compliances and certifications are also meant to cement trust. Healthcare is a particularly sensitive area in this regard because risks are huge, oftentimes the intervention cannot be reproduced and the procedure is irrevocable. Damage claims might also trigger legal actions over huge amounts of money, financial investments carry risks; therefore, $\mathrm{ROI}$ is on trembling legs which then generates yet more risks. Setting up a uniform AI ethical regulatory framework would be badly needed since this way compliance already can become very costly in the course of or after research. Healthcare provision risks are immense as early as in the clinical research phase which exists even without the use of an AI system as the ultimate goal of research is amelioration, diagnostics, therapy, and prevention in the field of rehabilitation by intervention or monitoring, while considering any deviating factors as applied in the normal course of healthcare provision (Act on Healthcare, Section 157). Under the Act on Healthcare (Section 164), for instance, "during research interests of the subject shall stand above those of science and society at all times." Thus, law strives to settle this ethical issue, the conflict of interest among patient, society and science. The interest of the patient is to get healed and stay healthy. The interest of society is to have as many healthy people as possible, whereas development, and the demonstration thereof, is what is in the interest of science. The legislator, therefore, holds that the interest of the patient, the subject is above all, anything else must be of lesser priority. So, for practical purposes, an AI healthcare system must be developed that prioritizes the individual and their interests. It is still an open question whether in a triage AI system the interests which individual's interests would be considered subject to equal opportunities if in that case prioritizing itself is the objective, i.e. establishing or denying priority to provide care for someone. That is the exact reason why this type of system is placed by the AI Code in the making among high-risk systems and requires extra guarantees of them (AI Code, Annex III, point 5. c/).

\section{Dilemmas Over AI's Development}

\section{A Prelude to "Non-Pixel"-based Diagnostics}

Can illnesses be predicted in a way that it is not based on previous measurements? If you can see better in the case of image processing technology thanks to AI, can you acquire the knowledge faster; if you look at language technology developments, can the volume of communications be multiplied; when it comes to voicedriven AI systems, are we going to be able to predict the risk of a disease more efficiently? It will continue to be very hard to replace physicians for a long time to come, their work will be made better, more efficient, faster and cheaper by devices, yet 
their responsibility will remain unchanged. For that matter radiology still runs on structured image databases, and it is still the doctor that does the diagnosis, they just get an efficient assisting tool, and ultimately the decision is made by the doctor after all. Questions might arise in relation to upcoming technology development opportunities, for instance, if we are going to be able make it happen technologically what might the future hold in medicine?

\section{Can bumanity remain human}

with superintelligence around?

ASI - artificial superintelligence is a development phase of AI systems where machines are capable of making autonomous decisions and even have consciousness and identity that surpasses the capabilities of AGI - artificial general intelligence, also called level two human intelligence. I find the science-fiction example (Adams, 1979) very compelling where supercomputer „Deep Thought” gives the answer of „42”, and yet nobody knows how and why it came up with it. Humanity must factor in this so-called Black Box effect with regard to AI systems in the case of which we will not be able to understand machine activity, and it's going to be hard to do so in healthcare in particular.

Human-like robots and almighty supercomputers functioning in a human form have been featured in literature, the film industry and fine arts countless times which raised a lot of medical, biological and legal issues. One example is the postbiology human in Hans Moravec's vision whose consciousness is placed in form of a "brain prosthesis" into a robotic body made of material that is a lot more resistant than the human body (Héder, 2020). This raises the question of self-identity of the human body and humans as such, and ultimately of their legal personality since the self-identity, self-image and selfconsciousness of the transplanted consciousness will be evidenced to itself in the new body; however, just because of that others won't be able to get assurance whether that particular person is the same or not.

Besides, if consciousness can be replicated once, then it can be done multiple times as well since human material does not get transformed in this vision but it is consciousness that ends up in a different body. In his book called Human 2.0 György Csepeli (2020) provides an overview of Ray Kurzweil's singularity definition according to which biological evolution equipped humans to be able to reach a level of development bound to happen through a technology evolution. In this case it is also a matter of discussion to what extent humans can self-identify with its human body, what percentage of it constitutes human self-identity, and what is the minimum of body functions that fulfils that criteria. In other words, to what point are we still the person that we were born to be during whose lifespan rights and obligations were acquired, who owns, 
possesses, marries and has descendants? If a nanotechnology intervention allows you to enter the neuron network of the brain, we can connect to it, stimulate or block it, or if we impact just the transmitter materials that carry over the stimulus in certain areas which makes it possible to change a human's personality, performance, temper, capabilities, mindset, would it be $\mathrm{OK}$ to create super soldiers or super minds?

If medical treatment of a raging or simply depressed patient takes place with the purpose of healing which can or must be executed even against their will if needed, it is legal in accordance with current regulations. If the same happened in the case of a non-chemical, nonmedicine-based, but invasive intervention, by using orally administered pill-formed nano robots or nano devices under remote control, which then start working in the desired area, how riskier would that be for the patient? It is more of a conspiracy theory that you could then control the tissue or the organ from the outside which is very much desirable against tumors in lieu of body damaging chemotherapy, or in the case of activating a paralyzed body part. Just like space travel has become available to those who can afford it, would a medical team perform procedures that promise patients smartness, strength, resistance, youth rather than beauty if they get paid enough?

In the sequel "Sapiens, The Brief History of Humankind" (Harari, 2020a) and "Homo Deus, The Brief History of
Tomorrow" (Harari, 2020b) the biological, psychological development of humankind is presented against the backdrop of economic, government and cultural history. We get a glimpse at dataism and technohumanism that value data most above all, and three questions are posed at the end of the latter piece that are also quasi statements. Firstly, organisms are algorithms and that life is data processing. Secondly, intelligence is decoupling from consciousness. Thirdly, non-conscious but highly intelligent algorithms may soon know us better than we know ourselves. So, according to this, superintelligence will not replace humans but rather becomes part of them?

\section{Can humans keep control over superintelligence?}

It is apparent that in the field of medicine physicians will keep control over machines for a very long time, so physicians' liability is here to stay. What remains to be seen is how lazy we would get as a result of an ever smarter machine intelligence? In order to counterweigh machine "overpower" or dominance, rules will be needed that make humans indispensable. But what makes it efficient? Don't we innovate to get machines to perform the most possible work better and more efficiently for us? The answer lies in establishing personally exercised human control; new structures, new systems, new legislation and new authorities need to be set up that are in the position to compete in terms of technology and capacity. 
As far as structure is concerned, power positions must be separated, just like it is the case in competition law where antitrust measures are needed to make a distinction in healthcare activities between those developing machines from those handling data and using AI systems, thus keeping each other under control and their position in the competition. Tilesch and Hatamleh (2021, p. 89) does an excellent job by describing the situation with the term "AI Eldorado" which will be caused by the fact that the development forecast by AI and its benefits are also growing exponentially. As a result, who enters the market first or achieves major breakthroughs in technology, they will have a full and immediate dominant position. The above-mentioned author fantastically gathers the measures that enable to preserve control, albeit referring to democracy and media, but let me add a few thoughts here that can work in the field of healthcare as well. Such an ethical smallest denominator at planning is the establishment of compassionate AI (see: Tilesch and Hatamleh, 2021, pp. 149 and 154) which takes into account soothing human pain and the social impact. Another such factor is setting up data ethics that takes into consideration in the course of putting together a learning database where all social and population groups are represented, and if necessary data domains are offset that might eventually discriminate against certain groups of people during subsequent operation. Thirdly, the harmonization of hundreds of different code of conducts must be mentioned; in healthcare these professional ethical rules are particularly of key importance which might even establish responsibility under criminal law. We might use technology of which regulatory background reflects the state of previous technology development, therefore it can cause legal uncertainty if someone is held accountable under outdated rules. Furthermore, public interest AI systems on the basis of joint developments of government and business stakeholders, operation of public interest test databases and test interfaces ("sandboxes"). Establishment of independent algorithm assessment and classification systems and apparatus proposed for the sake of transparency, creation of user trust index.

How does AI impact the physician-patient relationship?

Patients often complain that physicians get distracted by computers. At many places in the world there are no doctors around at all, so there computers and stateof-the-art tech are no obstacle to the physician-patient relationship but rather it makes it possible in the first place. Emerging countries are like that where digitalization doesn't replace doctors but rather makes up for the lack of them since the majority of the population already has cell phones, whilst medical care is not available in the area. In such a situation it cannot be expected to have two mandatory independent radiology specialist opinions for diagnosis, but is it permissible to 
provide help at least with machines in those areas if there are, indeed, no doctors?

We are not in a position to make decisions regarding the issue of doctor scarcity in emerging countries, but all over the world a certain level of information asymmetry does exist in the relationship between the principal (patient) and the physician (agent) which, economically speaking, is also a great example for supply-driven demand. In other words, you go to see the doctor by whom you are informed in a given and, for the sake of therapy, duly limited way, and then they tell you what healthcare service you need. An AI-driven telemedicine service, which is an information source with 24-houravailability, can soothe asymmetry, yet it must simultaneously observe a number of professional protocols, namely what and when can be shared with the patient by whom. Now, that is an expertise-bound question, and oftentimes the doctors can decide with view to the physical and mental state of the patient how they put what they've got to say. If there will be available complex AI systems that can recognize emotions, voices and images all at once, we would know more about the applicability of such telemedicine applications in healthcare. Doctors are understandably reluctant to use machine technology as they want to know whether AI takes away or over their tasks. Perhaps an interesting parallel can be drawn at this point with regard to the lawyer community where a similar approach can be experienced. In this connection Richard
Susskind (2017) gives a potential answer in his book where a number of new professions are listed that can be linked to new legal knowledge. Presumably this is what is going to happen in healthcare as well since a lot of people will be needed to design, develop, test, validate, adopt, teach and oversee technology.

Boosting the chance for healing at the expense of data protection?

Who wouldn't give everything to get themselves or a loved one healed? Health is the most precious treasure of humans, a one-time, unrepeatable thing that can be restored with huge difficulty once it's gone. If someone gave everything to get healed then why would they make an exception with their data, and can this be hindered by the legislator? What if someone's healthy, does not yet think about illness, but frequents screenings for the sake of prevention, pays for extra insurance, takes out a life insurance policy for the event of falling ill - can they be banned from letting their data be used for health preservation purposes? Even without the pandemic it can be clearly seen how important it is for scientific development that the possibly biggest number of people's biodiversity should enable us to compare as many of their data as possible. Therefore, when we talk about the fact that our smartwatch or other wearables collect our health data, and the manufacturer can access them, we are all upset, or we fool ourselves that they 
must be anonymized and we cannot be retraced. However, data linked to you certainly relates to one particular person, even if without a name, but by matching it against other data fragments, e.g. GPS coordinates, it can become distinctive within a particular group of data, and your phone, watch and other device knows it. What's more, in certain cases it is expressly desirable that it knows who is where and how they are feeling, if it's about your child's breathing monitor, or an incident suffered by your kin. Now, is this a preferable or evil future for these tools?

\section{Will healthcare finance become cheaper}

thanks to AI?

Cost-effectiveness is bound to go up as a result of more efficient healthcare management and more and more thorough AI-driven impact assessments supported by analytics. The continuous processing of the full spectrum of vast social security databases must be made available to health insurance, in the course of 'Qualy' calculation (which is attaching a number to the value of healthy lives) follow-up is needed to validate logical connections between funded procedures, medicine and the quality of life of those receiving care. The insured must be actively informed of the fact that they know and understand the consequences of their lifestyle, and they are aware of the costs of their treatment. By introducing tax and contribution breaks and monitoring wearables it can be incentivized and even checked whether someone does live a healthy life, and those doing regular exercise could be rewarded. Why should they pay more than those who don't care about their health? If such tech existed, would healthcare insurance cost less?

\section{Summary}

In the current phase of AI development, healthcare features mostly such machine learning methods in the field of diagnostics, management of diagnostic findings, prevention-purposed screening, or telemedicine that are in the development phase of the Artificial Narrow Intelligence. With quantum computing to take the stage in this decade which would allow the tech to be properly used, AI can look forward to a huge surge in computing capacity and development. During further development and innovation it is inevitable to review the current legislative logic and jurisprudence, though, before it becomes an obstacle to technology development. Detailed regulation exists on the level of EU law as well, which is complemented by extensive Member State regulations (on the level of acts and decrees), as well as guidelines, trade rules, national and local protocols, and code of conducts of different professional associations which are legally binding and can be enforced by court. It's going to be exciting to look back in a few years where we will have actually got from this rather comfortable standpoint of ours. See you in 5 years! 


\section{Reference}

1997/CLIV Act on Healthcare

Adams, D. (1979): The Hitchbiker's Guide to the Galaxy: Life, the Universe and Everything. Budapest (HU): Gabo

Csepeli, Gy. (2018): Human 2.0 Economic and social impact of Artificial Intelligence. Presentation in the Frame of 'Science in the Pub Series'. Date: Monday, 15 October 2018 at 6 p.m., Venue: Köszeg (HU), Tóth Vinery and Restaurant Kőszeg. Downloaded: 30th Nov. 2021. Web:

https://iask.hu/en/video/gyorgycsepeli-human-2-0-consequences-ofthe-artificial-intelligence/

Harari, Y. N. (2020a): Sapiens, The Brief History of Humankind. Budapest (HU): Animus Kiadó.

Harari, Y. N. (2020b): Homo Deus, The Brief History of Tomorrow. Budapest (HU): Animus Kiadó.

Héder, M. (2020): Artificial Intelligence, philosophical questions, practical answers. Budapest: Gondolat

MDR (Medical Devices Regulation): Regulation (EU) 2017/745 of the European Parliament and the Council. Downloaded: 30th Nov. 2021. Web: https://eur-lex.europa.eu/legalcontent/EN/TXT/PDF/?uri=CELE $\underline{\mathrm{X}: 32017 \mathrm{R} 0745}$
Proposal for $A$ Regulation of the European Parliament and of the Council Laying Down Harmonised Rules nn Artificial Intelligence (Artificial Intelligence Act) and Amending Certain Union Legislative Acts AI Code, Annex III, point 5. c/ Downloaded 30 Nov 2021 Web: https://eurlex.europa.eu/resource.html?uri=cellar :e0649735-a372-11eb-9585-

01aa75ed71a1.0001.02/DOC 1\&form at $=$ PDF

Susskind, R. (2017): Tomorrow's Lanyer, and introduction to your future. Oxford: Oxford University Press, p. 133

Tilesch, Gy. \& Hatamleh, O. (2021): Mesterség és intelligencia - Vegyük keqünkbe sorsunkat az. MI korában. Libri Könyvkiadó Kft., Budapest.

Zorkóczy, M. (2021): AI Vision \#1 Goodbye asymmetric information for Patients?! Mesterséges Intelligencia Folyóirat, III. évf. 2021/1. szám. 9-17. doi: 10.35406/MI.2021.1.9

Zorkóczy, M. (2021): Medical Law and Ethics-related Dimensions of Artificial Intelligence. MTA Law Working Papers - Institute for Legal Sciences, 2021/25, pp. 1-30. Downloaded: 30th Nov. 2021. Web:

https://jog.tk.hu/mtalwp/amesterseges-intelligencia-egeszsegugyijogi-es-etikai-dimenzioi 